\title{
Proximity of waterways to Finnish farmlands and associated characteristics of regional land use
}

\author{
Pirjo Peltonen-Sainio ${ }^{1 *}$, Heikki Laurila ${ }^{2}$, Lauri Jauhiainen ${ }^{1}$, Laura Alakukku \\ ${ }^{1}$ Natural Resources Institute Finland (Luke), Natural resources and bioproduction, Fl-31600 Jokioinen, Finland \\ ${ }^{2} \mathrm{CGI}$ Finland, Karvaamokuja 2, FI-00380 Helsinki, Finland \\ ${ }^{3}$ University of Helsinki, Department of Agricultural Sciences, P.O. Box 28, Fl-00014 University of Helsinki, Finland \\ email: pirjo.peltonen-sainio@luke.fi
}

\begin{abstract}
High latitude agriculture is rainfed. Climate change could, however, increase water deficiency and initiate a call for development of irrigation systems as a part of field water management systems. This study aimed to develop a basic understanding about the current state of irrigation potential according to region by monitoring proximity of fields to waterways and characterizing their general conditions. One third of Finnish fields are in direct contact with a shoreline of an inland waterway. This coupled with Finland being water-rich country may improve adaptive capacity to cope with the potentially harmful impacts of climate change in the future. However, there are marked differences between regions in access to water resources. Findings of this survey will serve as background information needed to assess future needs for introduction of irrigation and to evaluate the opportunities to close yield gaps and improve yield stability through irrigation.
\end{abstract}

Key words: distance, field, irrigation, land use, water availability

\section{Introduction}

Prehistoric settlement in Finland progressed in phases (Zvelebil and Rowley-Conwy 1984) and played a significant role in determining current land use, shaping the landscapes of the boreal regions. Forests, fields and waterways dominate the landscapes of Finland. In general, Finland is characterized as an exceptionally water-rich country owing to the forces caused by the $2-3 \mathrm{~km}$ thick ice sheet that covered the ground during the last glacial period of 10000 years ago.

Prehistoric lakeside settlements have been typical in Europe (Pollmann 2014). Humans have always utilized the combined ecological resources of land and water. As the coastal areas gradually emerged from the Baltic due to land upheaval, those with fine-grained mineral soils were available for settlement (Taavitsainen et al. 1998). Pollen analyses have interestingly revealed that traditional slash-and-burn cultivation was not the dominant practice in the coastal regions dedicated to agriculture, but cereals were grown in permanent fields while shore meadows offered feed for livestock (Wallin and Segerström 1994, Hansen 1998). However, due to post-glacial land upheaval, settlements were relocated from time to time to maintain the closeness to the seashore. Single farms were often the likely basis of the local settlement and typically such settlements again formed the basis of a firm organisation for society (Hansen 1998).

Hunter-gatherers and developing agrarian societies evidently benefitted in various ways from the ecosystem services that shoreline settlement offered. Despite the strategically beneficial location of farms and fields next to water, agriculture has not to date utilized thoroughly the ecosystem services provided by water availability. This is despite the fact the precipitation deficiency (difference between evapotranspiration and rainfall) during the first half of the growing season (May-July) in Finland has been estimated to be 100 to $250 \mathrm{~mm}$, being highest in the southern and western part of the country (Pajula and Triipponen 2003). Until recently farmers belittled the role of water scarcity as a frequent yield limiting constraint, possibly due to being misled by high annual precipitation and high spatial and temporal variation in precipitation (Peltonen-Sainio et al. 2011). Hence, despite abundant water reserves Finnish agriculture has always mainly been rainfed. Closeness to waterways has, however, provided advantageous microclimates that represent lower risks for night frosts interfering with crop growth, especially during the late and early growing season. 
Current access to water resources in Finnish agriculture can be considered as one of the manifestations of national-cultural heritage that prehistoric ancestors provided when they settled Finland and organised agrarian societies close to waterways. Even though high latitude agriculture has been rainfed to date, the future, with projected climate change induced increase in severity of water deficiency and occurrence in extreme events (IPCC 2012), may call for development and introduction of irrigation systems as an important component of comprehensive water management (drainage-irrigation-water protection) in boreal agriculture (Peltonen-Sainio et al. 2015a). As relevant around the world, this obliges development of water management strategies that integrate e.g. needs and means for changes in agricultural water use, conservation objectives and land use planning to prevent future harmful consequences (Jury and Waux 2007, Baker et al. 2014). Increased global demand for food is unlike without some expansion in irrigated area, as irrigated agriculture is $>300 \%$ as productive as rainfed agriculture and water scarcity will increase (Jury and Waux 2007). Increasing food production capacities by introduction of irrigation is feasible in regions like Finland with sufficient, high-quality water reserves.

With this study we aspired to compile a basic understanding about the state of irrigation potential in present day fields, according to region, by assessing closeness of fields to waterways. Furthermore, our objective as to characterize, in general, field conditions and land use depending on how close they were to inland waterways. The gained novel understanding serves as basic background information when planning and developing assessments on future potential for irrigation in Finland, i.e. estimating current and future yield gaps and elaborating further opportunities to narrow the gaps and increase yield stability through irrigation in a socially acceptable and economically viable and rational way.

\section{Materials and methods Data sources and their elaboration}

The data used in this study consisted of four spatial vector and raster datasets (i)-(iv) each analyzed as separate layers in a common Geographical Information System (GIS) with a common EUREF-FIN (TM35FIN/ETRS89) coordinate system using a Transverse Mercator map projection: (i) the digitized vector boundaries for the Centre for Economic Development, Transport and the Environment (ELY) Centres in Finland, (ii) MTT Agrifood Research Finland spatial soil database, (iii) the Agency for Rural Affairs (MAVI) official Field Parcel Identification System (FLPIS 2014) database with digitized field parcels for all cultivated agricultural land in Finland, and (iv) NLS (National Land Survey of Finland) dataset, containing both topographic coordinate data and other spatial attribute data like waterway width, classification code and spatial type (line, polygon) for surface and irrigation water resources (ditches, rivers and lakes) in Finland (NLS 2014).

The ELY dataset consisted of 16 digitized boundaries (of type line) for the ELY centres in Finland (Fig. 1). The MTT soil dataset consisted of digitized polygons with major soil classification types in Finland (Lilja et al. 2009). The MAVI dataset consisted of digitized fields (type polygon) in Finland. The NLS dataset consisted of digitized (1) main ditches (NLS class code 36312, width 2-10 m, spatial type line), (2) rivers (NLS code 36313, width >10 m, type polygon), and (3) lakes (NLS code 36200, type polygon).

\section{Model}

With the following multi-phase process we aimed to categorise how the Finnish cropland falls into different distance ranges from surface waters. ArcGIS (v. 10.2) software from the Environmental Systems Research Institute (ESRI) with the ArcMap Geoprocessing tool for spatial analysis was used to analyze the four spatial datasets (i-iv) used in this study. Two ArcMap components in Geoprocessing toolset using ArcMap ModelBuilder were used in spatial analysis: (a) Buffering Analysis and (b) Intersect Analysis components.

The Buffering Analysis component creates buffer polygons around input features to a specified distance. In this study the Buffering Analysis component was used to calculate the 50, 100 and 300 metre buffering zones (of spatial type line) around ditches, rivers and lakes obtained from the NLS dataset (iv).

The Intersect Analysis component computes a geometric intersection covariance of the input layers using map algebra rules. The result of the intersect analysis consists of layers or portions of layers which overlap in all input layers. In this study the Intersect Analysis was used to calculate the spatial intersection covariance components (polygons and lines) interacting between the four spatial datasets (i-iv). The common EUREF-FIN coordinate system was applied for four overlaying GIS layers digitized as spatial polygons and lines. 
The general solution for the spatial intersection method with covariance effects, buffering analysis, and calculation hierarchy is given in Eq. 1. During the spatial analysis process, the spatial buffering line results $\left(x_{4}\right)$ were intersected with polygon component results $\left(x_{1}, x_{2}, x_{3}\right)$.

intersection $\left[\left(x_{1}\right) \times\left(x_{2}\right) \times\left(x_{3}\right) \times\left(\right.\right.$ buffering $\left.\left.\left(x_{4}\right)\right)\right]$

where the intersect covariances were: $\left(x_{1}\right)$ a digitized region polygon (The Centres for Economic Development, Transport and the Environment, ELY Centres, total of 16$),\left(x_{2}\right)$ the MTT soil polygon inside a specific ELY region polygon, $\left(x_{3}\right)$ the MAVI field parcel polygon within a specific ELY region polygon and corresponding overlaying MTT soil polygon (totalling about 1 million field base parcels), and $\left(x_{4}\right)$ the buffered distance line $(50,100,300 \mathrm{~m})$ from the waterway $(0 \mathrm{~m}$ ) within specific (MAVI field parcel polygon $\times$ MTT soil polygon $\times$ ELY centre region polygon) intersection. In addition, during buffering analysis in component $\left(x_{4}\right)$, a requirement was forced for each field parcel having either shoreline to waterway or being $\leq 50 \mathrm{~m}, \leq 100 \mathrm{~m}, \leq 300 \mathrm{~m}$ or $>300 \mathrm{~m}$ distant from the corresponding shoreline) depending on the waterway (being either main lake, river or main ditch).

In this paper we use term "field" when referring to field parcels available from FLPIS. These fields are often further divided into agricultural parcels. Thereby, in one field there might be number of agricultural parcels that differ by crop species.

Cultivation information was obtained from MAVI (official database for field crop cultivation). The register had 1213038 agricultural parcels from 1026934 fields. 1143147 agricultural parcels had following information: cultivation area, farmer, crop, municipality and ELY-centre in 2011. In addition, mid-point coordinates were available for 852303 fields.

The national field parcel register and the database of water access were combined. Descriptive statistics (mean, lower quartile, median, upper quartile) were used to calculate water access distribution in different ELY-centres. In addition, similar calculations were done separately for several crops and results were compared to the distribution of all crops. Descriptive statistics were used to compare average area of agricultural parcels between different water access categories. Spatial distribution of water access categories was illustrated by $10 \times 10 \mathrm{~km}$ maps with background maps of 1:80 000 by Maanmittauslaitos (National Land Survey of Finland).

The soil map database (Lilja et al. 2009) included information on soil type from 571808 fields. The database was combined with the database for water access and distribution of water access was calculated for all soil types.

Weather data originating from the Finnish Meteorological Institute was gathered for 2010, when specific information was available for irrigation practices on Finnish farms (Tike 2012). As drought has most detrimental effects on crop growth and yield formation at early to mid summer (Peltonen-Sainio et al. 2011), information on monthly accumulated precipitation $(\mathrm{mm})$, mean temperature $\left({ }^{\circ} \mathrm{C}\right)$ and cumulated degree days $\left({ }^{\circ} \mathrm{C}\right)$ for May, June and July in 2010 was compared with the long-term mean (1981-2000) for eight regional meteorological stations.

\section{Results}

\section{Regional differences in field closeness to waterway shorelines and field characteristics}

At the national scale one third of the fields are located next to waterways, lakes, rivers and main ditches, and slightly more than another third are within $300 \mathrm{~m}$ of the shoreline of a waterway (Fig. 1), when sea shorelines were excluded.

Hence, only one quarter of the fields is more than $300 \mathrm{~m}$ from a waterway. However, regional differences are significant: the highest share of fields is close to waterways in western coastal regions that are characterized by a high number of outlets. In the archipelago and southern coastal and eastern interior regions the proportion of fields with reasonable closeness to waterways is lowest, but even then 20-35 percent of fields were located near the waterways and even more in the Great Lakes District of Finland (Fig. 1).

The number of fields and agricultural parcels within a main field change substantially, depending on region. As the total number of agricultural parcels included in this study was ca. 960000, the range depending on region varied from 111000 agricultural parcels in Etelä-Pohjanmaa and 98000 in Varsinais-Suomi to 12000 in the archipelago (mainly Åland) and 18000 in northern interior Kainuu. At the national scale $86.9 \%$ of fields were not divided into agricultural parcels in 2011, ranging from $83.7 \%$ to $91.2 \%$ depending on region (data not shown). 
In the case of having agricultural parcels, fields were divided into two up to five or even eight parcels depending on region and the field size (Fig. 2): typically the biggest fields had the highest number of agricultural parcels, but the sizes of agricultural parcels within a field were not equal.

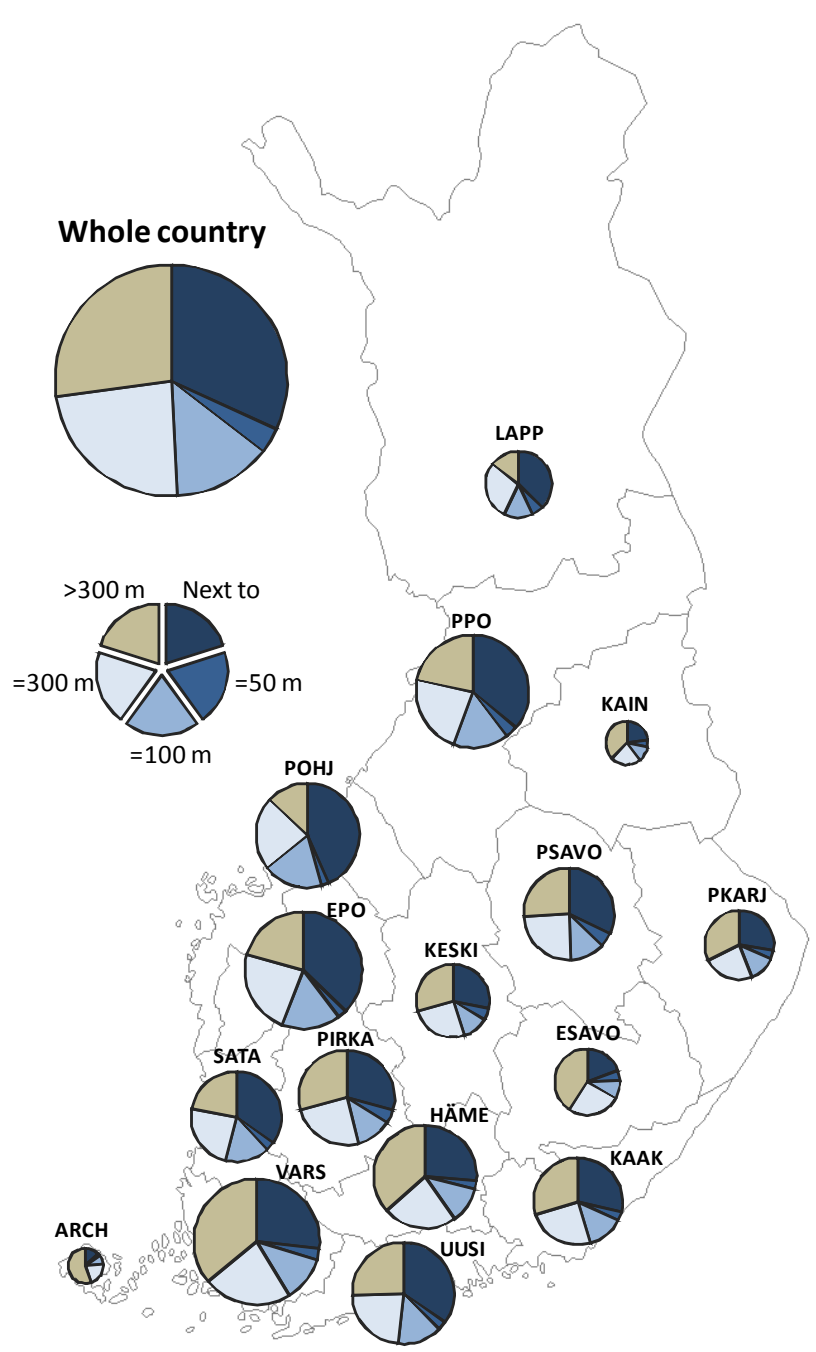

Fig. 1. Closeness of fields to waterways depending on region. The size of the circle indicates the total area (ha) of arable land in each region compared with VarsinaisSuomi as a reference (with the total of 296630 ha in 2011). Regions: UUSI, Uusimaa (1 in Fig. 4); VARS, Varsinais-Suomi (2); SATA, Satakunta (3); HÄME, Häme (4); PIRKA, Pirkanmaa (5); KAAK, Kaakkois-Suomi (6); ESAVO, Etelä-Savo (7); PSAVO, Pohjois-Savo (8); PKARJ, Pohjois-Karjala (9); KESKI, Keski-Suomi (10); EPO, EteläPohjanmaa (11); POHJ, Pohjanmaa (12); PPO, PohjoisPohjanmaa (13); KAIN, Kainuu (14); LAPP, Lapplan (15); ARCH, Archipelago [Åland Islands (16)].
Size of field and size distribution of agricultural parcel in it (ha)

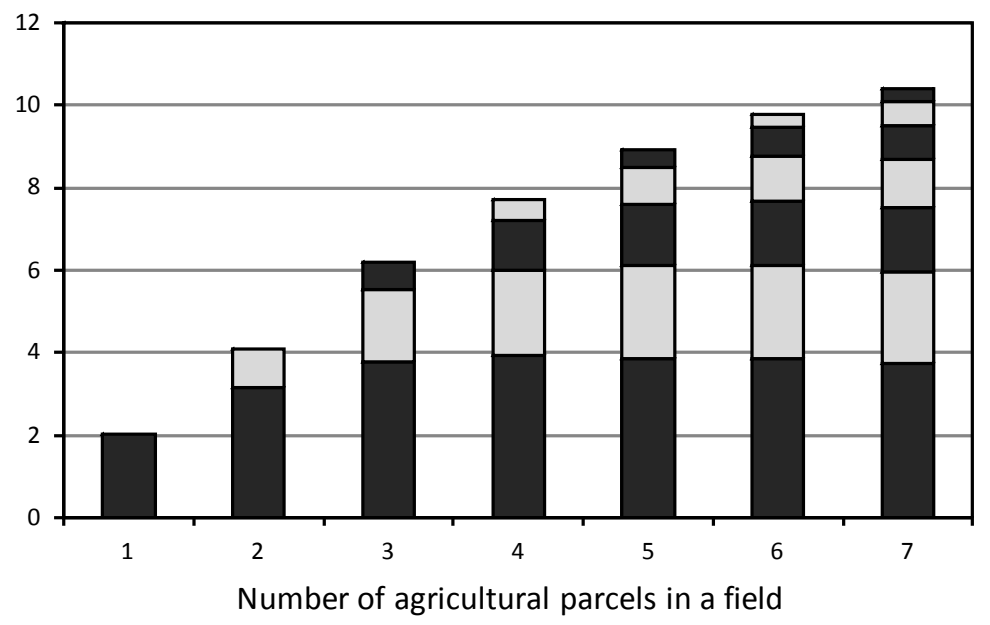

Fig. 2. The mean number and size distribution of agricultural parcels depending on the area of the field. The parcel size distribution within a field is shown with alternating black and gray. 
There was also a tendency that the fields and also agricultural parcels right next to the waterway, especially river and main ditch, were bigger than those more distant from waterways (Fig. 3).
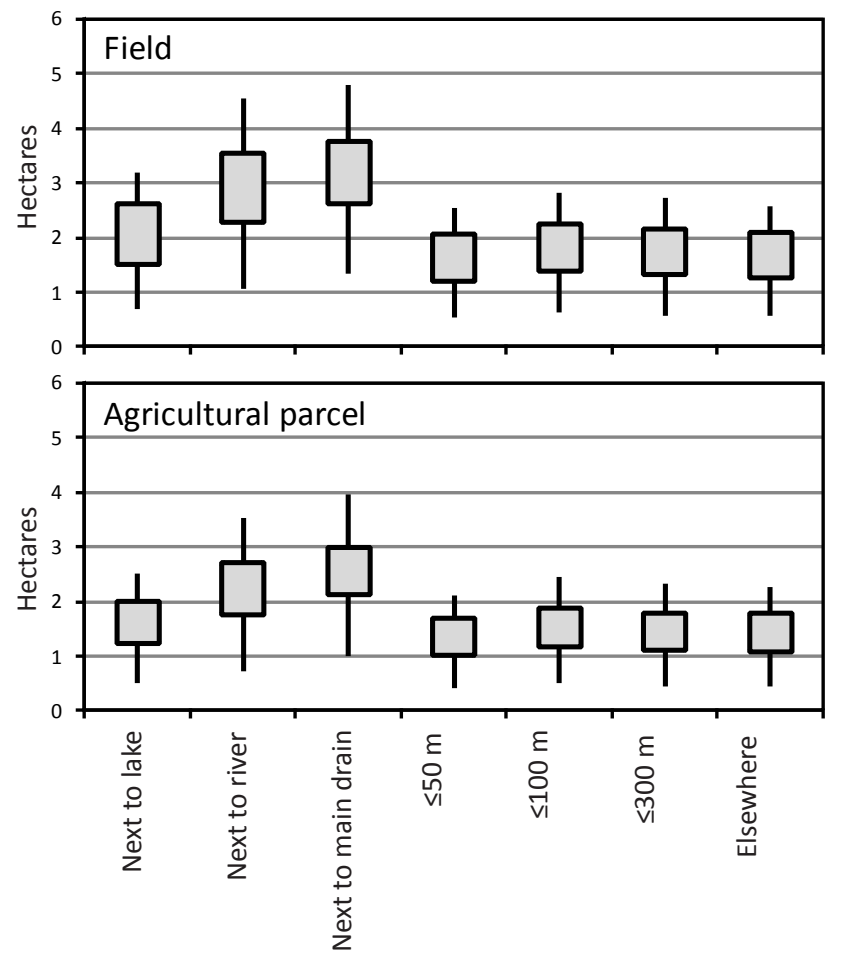

Fig. 3. Field size depending on closeness to waterway compared with fields located at a distance. The upper part of the line indicates upper quartile, the lower part of line lower quartile, the top of the box mean field size (ha) and the bottom of the box median for field size.

This was the case independent of region, though regional differences in general field size distributions were high. Particularly large fields were located next to lakes, rivers and main ditches in the southern and south-western prime cereal production regions, Uusimaa, Varsinais-Suomi, Satakunta and Pirkanmaa (Fig. 4). Field size at $<50$, $<100$ and $<300 \mathrm{~m}$ from waterways were, however, very similar in size compared with those even further from any waterway (data not shown).
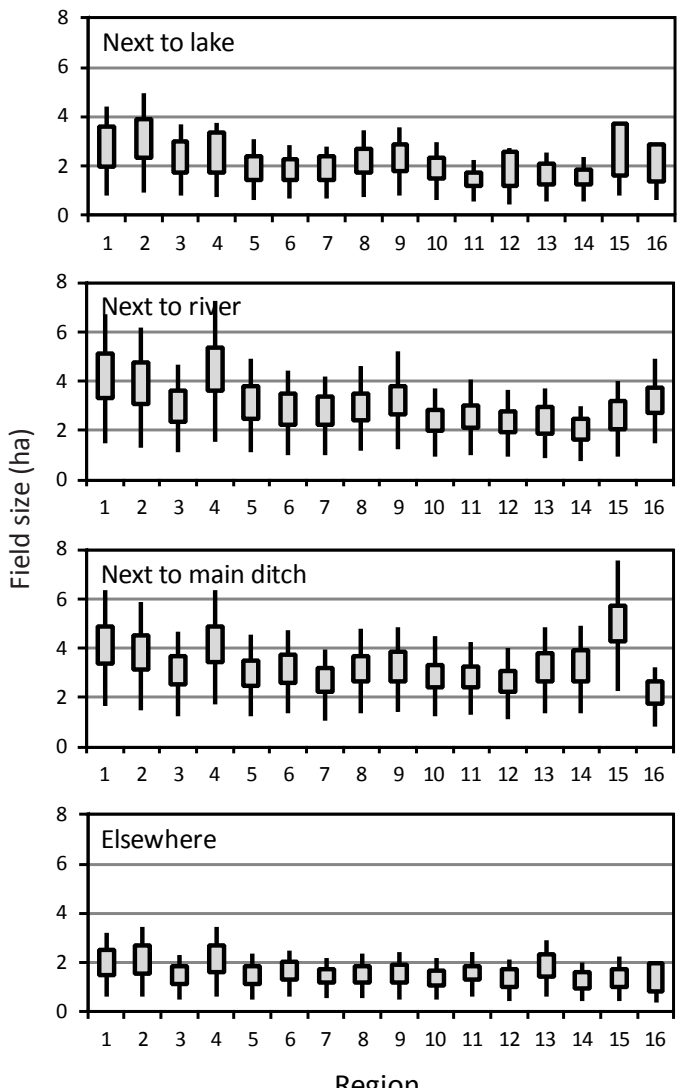

Fig. 4. Regional differences in field size (ha) next to lake, river, main ditch and elsewhere ( $\geq 300 \mathrm{~m}$ from waterways). The upper part of the line indicates upper quartile, the lower part of line lower quartile, the top of the box mean field size (ha) and the bottom of the box median for field size. Regions, see Figure 1. 
The portfolio of field crops grown in different regions has not fluctuated much within a region in recent three decades though major differences between regions exist, with e.g. large areas under grass crops in northern and eastern parts of Finland and the domination of cereal and other seed crops in the coastal and southern inland regions (Fig. 5).

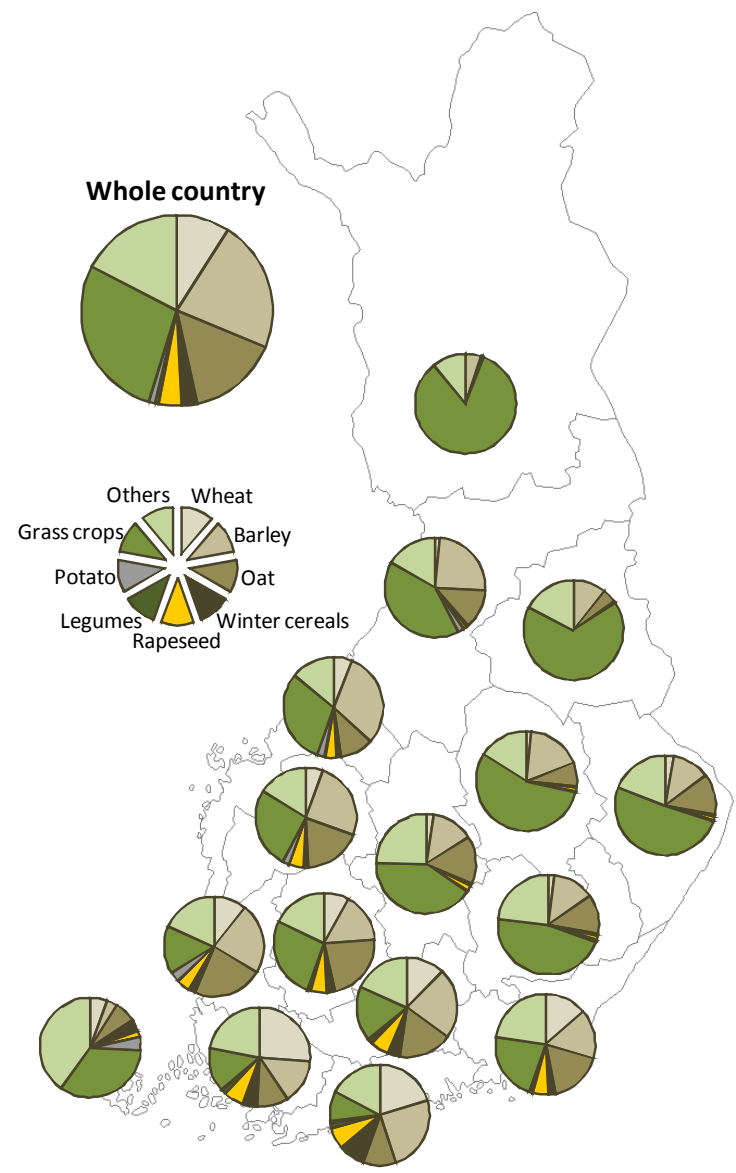

Fig. 5. Regional differences in land use in crop production in 2011 (Data from Tike). Regions, see Figure 1.

Climatic conditions, especially temperature-related length of the growing season and risk for night frost, are among the main climatic factors shaping the land use in addition to edaphic factors that differ regionally. For example, fine mineral soils like fine sand and silt (Eutric Regosol) and clay soils (Vertic Cambiosol) dominate close to waterways while till soils (Haplic Podzol 1) are typical of fields distant from waterways (Fig. 6). Organic soils are infrequent both close to and apart from waterways.

$\square$ Next to waterway $\quad \square \leq 300 \mathrm{~m}$ apart $\quad \square>300 \mathrm{~m}$ apart

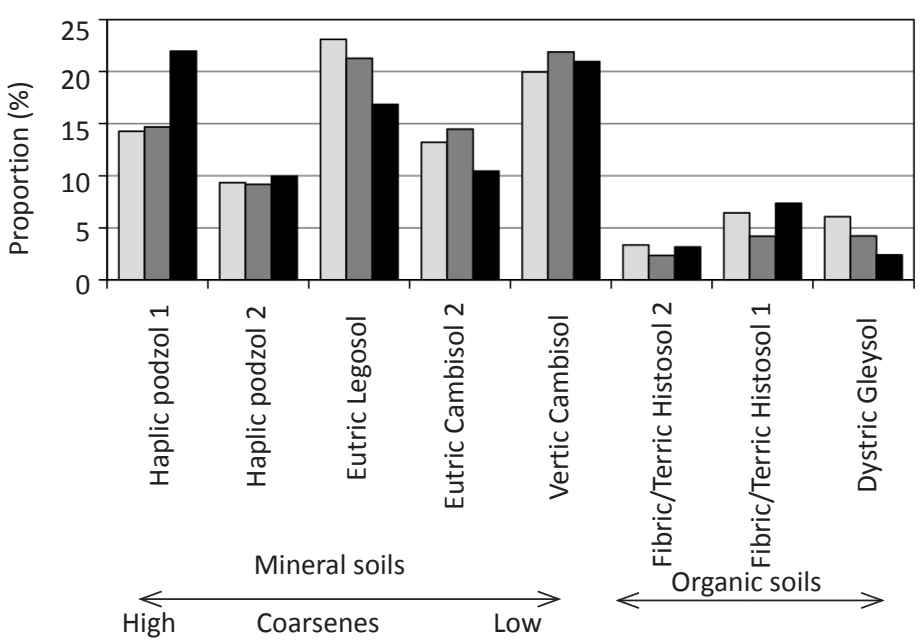

Fig. 6. Frequency of different soil types in fields next to waterway, up to $300 \mathrm{~m}$ from waterway and elsewhere. Data from Luke Soil Database (Lilja et al. 2009). 


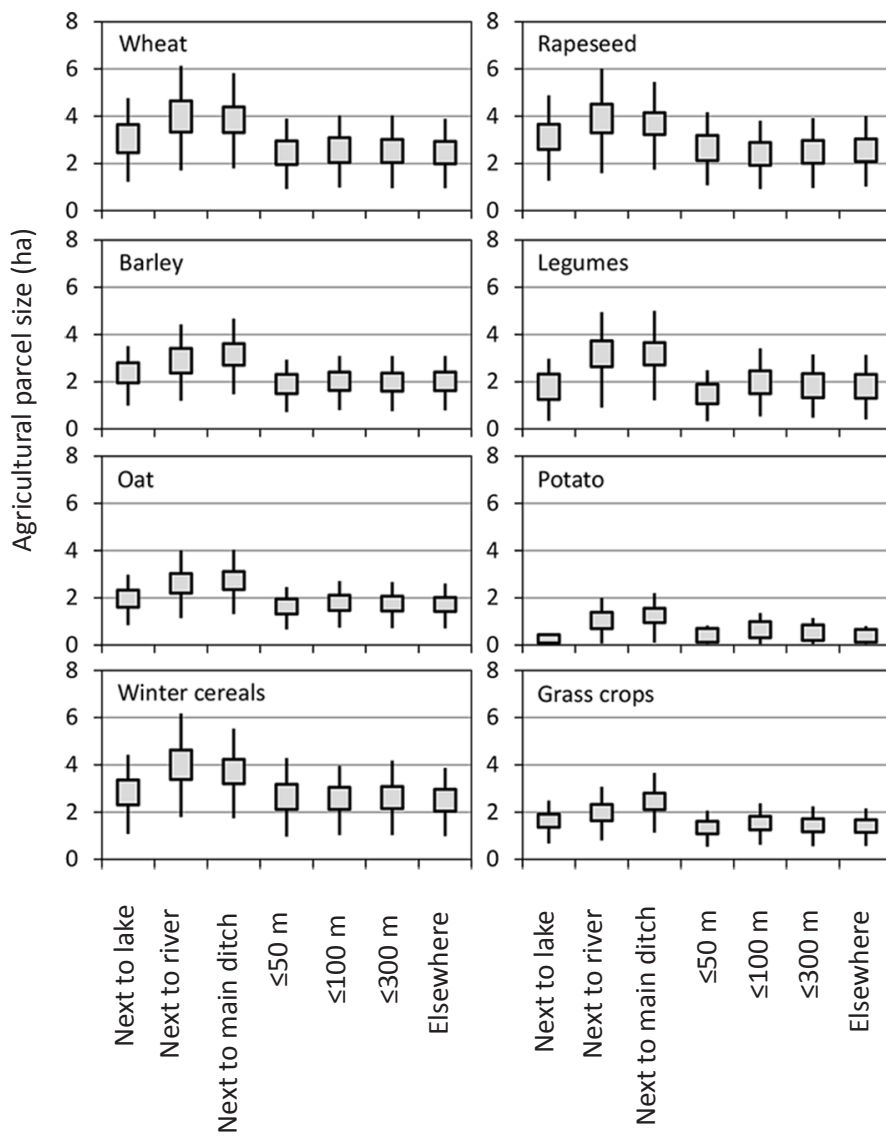

Fig. 7. Differences between crops in agricultural parcel size (ha) depending on closeness to waterways in 2011. The upper part of the line indicates upper quartile, the lower part of line lower quartile, the top of the box mean field size (ha) and the bottom of the box median for parcel size.

This is attributable to the generally larger fields along the shoreline of waterways (Figs. 3 and 4). Agricultural parcels devoted to potato (Solanum tuberosum L.) are particularly small, especially next to lakes (Fig.7). When regions were compared the same held, independently of the frequency of waterways and fields next to them in a region - the larger fields and agricultural parcels were next to the rivers and main ditches (Fig. 8).

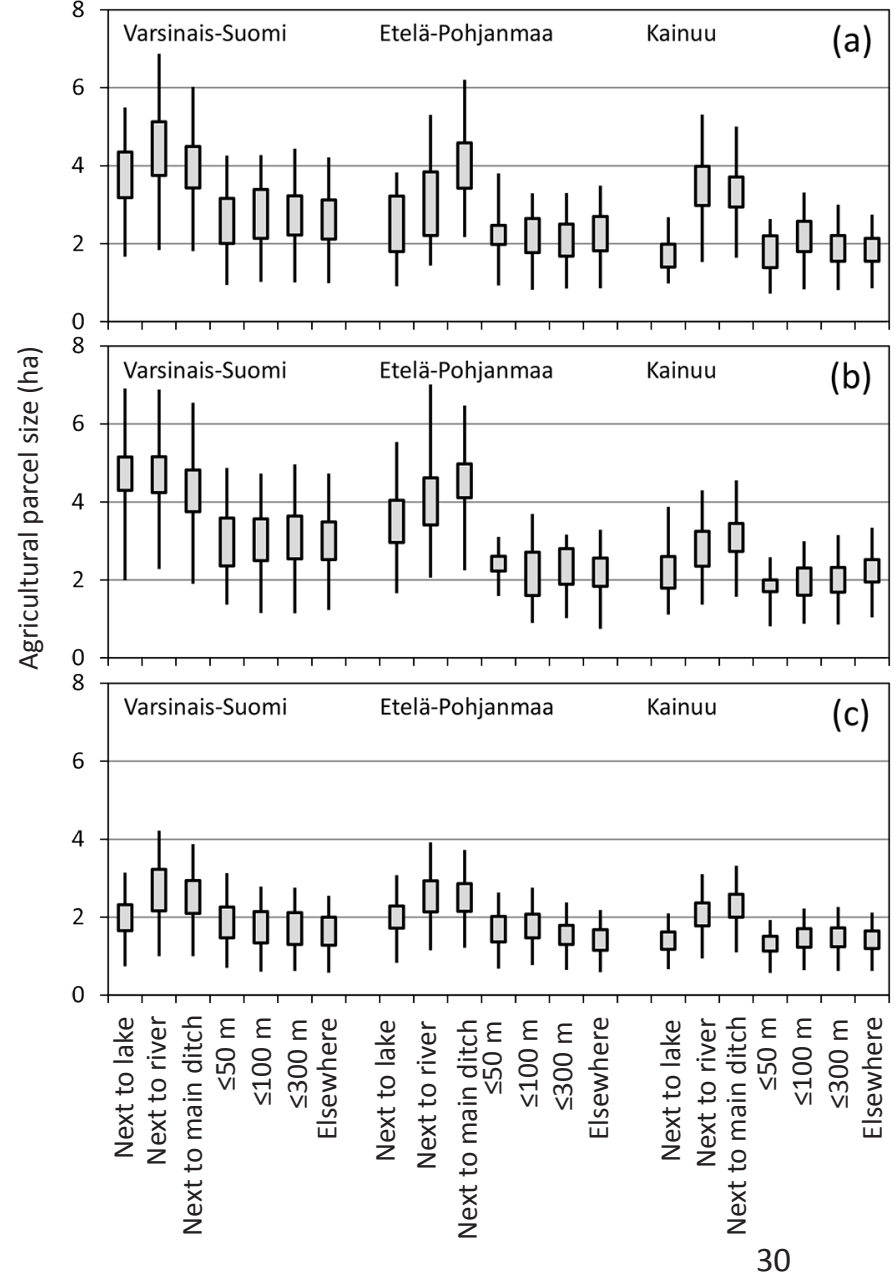

Fig. 8. Differences between major and minor production regions in agricultural parcel size devoted to spring wheat (a), rapeseed (b) and grass crops (c). The upper part of the line indicates upper quartile, the lower part of line lower quartile, the top of the box mean parcel size (ha) and the bottom of the box median for field size. 
When further assessing how common each major crop was near a waterway relative to the general proportion of cultivated land in a region or on the national scale, we found that potato was more frequently grown next to waterways than any other crop despite large regional differences (Table 1). Also for crops other than oat (Avena sativa L.) and pasture higher proportions of land were devoted to their cultivation in agricultural parcels close to waterways than elsewhere.

Table 1. Percentage of crop grown in fields close to waterways and elsewhere compared with general cropping percentage (\% / \%) at national (CO) level and in the region (REG) with the highest percentage (i.e., 1.00 refers to equal percentage at national scale, $<1.00$ lower percentage and $>1.00$ higher percentage compared with national or regional scale). Also proportion of fields with buffer zones (\%) (area being at least $15 \mathrm{~m}$ from shoreline) incentivized by the Agri-Environmental Program is shown at national and regional scale. Data for 2011 provided by Tike.

\begin{tabular}{|c|c|c|c|c|c|c|c|c|c|c|c|c|c|c|c|c|}
\hline \multirow[t]{2}{*}{$\begin{array}{l}\text { Closeness to } \\
\text { waterway }\end{array}$} & \multicolumn{2}{|c|}{ Wheat } & \multicolumn{2}{|c|}{ Barley } & \multicolumn{2}{|c|}{ Oat } & \multicolumn{2}{|c|}{$\begin{array}{l}\text { Winter } \\
\text { cereals }\end{array}$} & \multicolumn{2}{|c|}{ Rapeseed } & \multicolumn{2}{|c|}{ Potato } & \multicolumn{2}{|c|}{$\begin{array}{l}\text { Grass } \\
\text { crops }\end{array}$} & \multicolumn{2}{|c|}{$\begin{array}{l}\text { Buffer } \\
\text { zone }\end{array}$} \\
\hline & $\mathrm{CO}$ & REG & $\mathrm{CO}$ & REG & $\mathrm{CO}$ & REG & $\mathrm{CO}$ & REG & $\mathrm{CO}$ & REG & $\mathrm{CO}$ & REG & $\mathrm{CO}$ & REG & $\mathrm{CO}$ & REG \\
\hline Next to lake & 0.63 & 1.88 & 0.75 & 1.19 & 0.87 & 1.14 & 0.76 & 2.84 & 0.72 & 1.22 & 0.43 & 2.74 & 1.19 & 1.46 & 1.55 & 5.01 \\
\hline Next to river & 1.28 & 3.33 & 1.17 & 1.53 & 0.87 & 1.91 & 1.23 & 8.20 & 1.14 & 2.51 & 1.39 & 2.95 & 0.91 & 1.12 & 1.50 & 5.61 \\
\hline Next to ditch & 1.19 & 1.57 & 1.24 & 2.10 & 1.05 & 1.91 & 1.05 & 1.97 & 1.20 & 1.92 & 1.36 & 2.93 & 0.85 & 1.15 & 0.50 & 1.79 \\
\hline$\leq 50 \mathrm{~m}$ & 0.78 & 1.46 & 0.91 & 1.20 & 0.90 & 1.08 & 0.97 & 1.75 & 0.88 & 1.87 & 0.84 & 1.76 & 1.16 & 1.26 & 1.55 & 5.61 \\
\hline$\leq 100 \mathrm{~m}$ & 0.99 & 1.50 & 1.07 & 1.45 & 1.03 & 1.41 & 0.92 & 2.33 & 1.02 & 3.03 & 1.08 & 1.50 & 0.99 & 1.17 & 0.92 & 3.37 \\
\hline$\leq 300 \mathrm{~m}$ & 0.96 & 3.54 & 0.96 & 1.18 & 1.02 & 1.33 & 1.01 & 1.61 & 0.96 & 2.26 & 1.01 & 1.62 & 1.06 & 1.25 & 0.57 & 1.71 \\
\hline Elsewhere & 0.94 & 1.01 & 0.86 & 1.06 & 1.02 & 1.10 & 1.00 & 1.06 & 0.93 & 1.44 & 0.75 & 1.74 & 1.02 & 1.31 & 0.27 & 0.73 \\
\hline
\end{tabular}

\section{Current irrigation capacity}

The proportion of farms with existing irrigation technology averaged $7.2 \%$ in Finland, with high regional differences and particularly high irrigation capacity in the archipelago, Varsinais-Suomi and Uusimaa regions, and low in northern regions of the country (Table 2). The potential area accessed by irrigation technologies ranged from 0.5 $\%$ to $10.3 \%$, depending on region, with a national mean of only $3.0 \%$. Even in the cases that a farm has irrigation facilities, only some of the fields can be irrigated, i.e. from $22.2 \%$ to $40.9 \%$ of the farm area (Table 2). On average, about one third of the farm area is available for irrigation considering farms that have irrigation equipment.

Drought and elevated temperatures were experienced from mid summer 2010 (Table 3), i.e. when yield potential was determined, but especially so when it was realized as yields. 
P. Peltonen-Sainio et al. (2015) 24: 24-38

Table 2. Regional differences in proportion of farms with irrigation technologies (\%) and proportion of arable land available for irrigation (\%) in 2010. Regions: UUSI, Uusimaa; VARS, Vasinais-Suomi; SATA, Satakunta; HÄME, Häme; PIRKA, Pirkanmaa; KAAK, Kaakkois-Suomi; ESAVO, Etelä-Savo; PSAVO, Pohjois-Savo; PKARJ, Pohjois-Karjala; KESKI, Keski-Suomi; EPO, Etelä-Pohjanmaa; POHJ, Pohjanmaa; PPO, Pohjois-Pohjanmaa; KAIN, Kainuu; LAPP, Lapplan; ARCH, Archipelago. See regions in map in Figure 1. Data from Tike (2012).

\begin{tabular}{lccc}
\hline \multirow{2}{*}{ Region } & Farms with irrigation technologies & \multicolumn{2}{c}{ Potential area for irrigation } \\
\cline { 3 - 4 } & & At regional scale & At irrigation farm scale \\
\hline UUSI & 11.2 & 5.3 & 38.5 \\
VARS & 15.6 & 5.2 & 30.4 \\
SATA & 8.5 & 4.2 & 38.2 \\
HÄME & 8.4 & 3.8 & 31.9 \\
PIRKA & 5.4 & 2.9 & 38.9 \\
KAAK & 8.1 & 3.3 & 35.9 \\
ESAVO & 8.5 & 3.8 & 38.5 \\
PSAVO & 7.1 & 2.0 & 32.7 \\
PKARJ & 4.0 & 1.1 & 34.1 \\
KESKI & 3.8 & 1.0 & 24.4 \\
EPO & 3.2 & 1.1 & 31.0 \\
POHJ & 3.9 & 1.9 & 40.9 \\
PPO & 4.3 & 1.7 & 32.2 \\
KAIN & 4.1 & 0.8 & 28.5 \\
LAPP & 3.2 & 0.5 & 22.5 \\
ARCH & 28.8 & 10.3 & 35.6 \\
At national scale & 7.2 & 3.0 & 34.1 \\
\hline
\end{tabular}

Table 3. Deviation of May, June and July mean temperature $\left(\operatorname{Tmean},{ }^{\circ} \mathrm{C}\right)$, cumulated degree days $\left(\mathrm{CDD},{ }^{\circ} \mathrm{C}\right)$ and accumulated precipitation (Prec, $\mathrm{mm}$ ) from long-term mean (1981-2010) in eight meteorological stations of Finland in 2010. See regions in Table 2 and Figure 1. Data from Finnish Meteorological Institute.

\begin{tabular}{|c|c|c|c|c|c|}
\hline \multicolumn{2}{|l|}{ Station } & \multirow[b]{2}{*}{ Month" } & \multicolumn{3}{|c|}{ Deviation from long-term mean } \\
\hline Name (coordinates) & Region & & Tmean & CDD & Prec \\
\hline \multirow[t]{3}{*}{ Jomala $(60.12,19.90)$} & $\mathrm{ARCH}$ & May & 0.5 & 23.8 & 7.5 \\
\hline & & June & -0.3 & -16.7 & -28.8 \\
\hline & & July & 3.2 & 112.8 & -41.8 \\
\hline \multirow[t]{3}{*}{ Jokioinen $(60.81,23.50)$} & HÄME & May & -5.0 & 46.9 & 27.0 \\
\hline & & June & 0.0 & 0.7 & -10.3 \\
\hline & & July & 4.1 & 127.2 & -33.5 \\
\hline \multirow[t]{3}{*}{ Lappeenranta $(61.04,28.15)$} & KAAK & May & -4.0 & 59.3 & 20.3 \\
\hline & & June & 0.0 & 13.6 & -19.9 \\
\hline & & July & 5.0 & 154.7 & -20.5 \\
\hline \multirow[t]{3}{*}{ Jyväskylä $(62.40,25.67)$} & KESKI & May & -4.9 & 64.7 & 26.7 \\
\hline & & June & -0.4 & 1.0 & -13.7 \\
\hline & & July & 4.6 & 143.7 & -57.2 \\
\hline \multirow[t]{3}{*}{ Tohmajärvi $(62.24,30.35)$} & PKARJ & May & 3.0 & 69.4 & 10.3 \\
\hline & & June & -1.0 & -30.5 & 0.5 \\
\hline & & July & 4.4 & 136.4 & -4.8 \\
\hline \multirow[t]{3}{*}{ Seinäjoki $(62.94,22.49)$} & EPO & May & 2.2 & 68.6 & 28.3 \\
\hline & & June & -0.5 & -14.2 & -14.6 \\
\hline & & July & 3.6 & 112.8 & 0.1 \\
\hline \multirow[t]{3}{*}{ Oulunsalo $(64.93,25.35)$} & PPO & May & 3.1 & 100.6 & -12.5 \\
\hline & & June & -1.4 & -42.2 & -13.3 \\
\hline & & July & 2.2 & 68.0 & -11.5 \\
\hline \multirow[t]{3}{*}{ Rovaniemi $(66.58,26.01)$} & LAPP & May & 2.1 & 92.3 & -1.4 \\
\hline & & June & -1.4 & -36.7 & -32.2 \\
\hline & & July & 0.6 & 23.5 & 5.4 \\
\hline
\end{tabular}


Accumulated precipitation in $\mathbf{2 0 1 0}$ was clearly less than the long-term mean for June and July, especially across the prime agricultural regions of Finland, and was accompanied by elevated temperatures and more cumulated degree days, particularly in July (and continuing so also in August). Of farms with existing irrigation technologies (7.2\% of farms), $3.7 \%$ exploited the opportunity for irrigation (Table 4).

Table 4. Regional differences in proportion of irrigated farms (\%) in 2010 and the proportion of area that was irrigated to cope with drought (\%). See regions in Table 2 and Fig. 1. Data from Tike (2012).

\begin{tabular}{|c|c|c|c|c|}
\hline \multirow[b]{2}{*}{ Region } & \multirow{2}{*}{$\begin{array}{l}\text { Proportion of irrigated } \\
\text { farms }\end{array}$} & \multicolumn{3}{|c|}{ Proportion of irrigated area to cope with drought } \\
\hline & & At regional scale & $\begin{array}{l}\text { At irrigation farm } \\
\text { scale }\end{array}$ & From area accessible for irrigation \\
\hline UUSI & 4.4 & 0.5 & 3.8 & 9.8 \\
\hline VARS & 9.4 & 0.9 & 5.4 & 17.8 \\
\hline SATA & 4.2 & 0.9 & 8.3 & 21.8 \\
\hline HÄME & 3.6 & 0.6 & 4.9 & 15.5 \\
\hline PIRKA & 1.7 & 0.2 & 3.3 & 8.2 \\
\hline KAAK & 3.5 & 0.5 & 5.0 & 13.9 \\
\hline ESAVO & 5.3 & 1.3 & 13.4 & 34.8 \\
\hline PSAVO & 4.0 & 0.6 & 9.3 & 28.4 \\
\hline PKARJ & 2.5 & 0.3 & 10.8 & 31.7 \\
\hline KESKI & 2.0 & 0.1 & 3.3 & 13.7 \\
\hline EPO & 1.3 & 0.2 & 5.8 & 18.6 \\
\hline $\mathrm{POHJ}$ & 2.1 & 0.6 & 12.7 & 31.0 \\
\hline PPO & 2.0 & 0.3 & 6.4 & 19.9 \\
\hline KAIN & 1.5 & 0.1 & 2.6 & 9.1 \\
\hline LAPP & 1.8 & 0.1 & 5.0 & 22.1 \\
\hline ARCH & 18.7 & 4.4 & 15.2 & 42.6 \\
\hline At national scale & 3.7 & 0.6 & 6.4 & 18.7 \\
\hline
\end{tabular}

Depending on region, up to $4.4 \%$ of the arable land was irrigated in 2010 to cope with drought, but the national mean was only $0.6 \%$. Furthermore, $6.4 \%$ of the area was irrigated on farms with facilities for irrigation and 18.7 $\%$ of the area of farms that had potential for irrigation. In most cases surface water was used for irrigation, coming from a waterway extending beyond the farm (38.6-83.8 \% of water used) (Table 5).

Depending on region, surface water on the farm was an important source for irrigation (10.3-49.4 \%), while groundwater and tap water were only rarely used. In horticulture (the dominant sector for irrigation) more onfarm surface water was used than for special crop and potato production. 
Table 5. Origin of irrigation water (\%) in 2010 according production sector and regions (surface water from the farm or from a waterway that extends beyond the farm, groundwater from the farm, tap water from outside the farm and other source of water). See regions in Table 2 and Figure 1. Data from Tike (2012).

\begin{tabular}{|c|c|c|c|c|c|}
\hline \multirow[b]{2}{*}{ Production sector } & \multicolumn{2}{|c|}{ Surface water } & \multirow{2}{*}{$\frac{\text { Groundwater }}{\text { Farm }}$} & \multirow{2}{*}{$\begin{array}{c}\text { Tap water } \\
\text { Beyond the farm }\end{array}$} & \multirow[t]{2}{*}{ Other } \\
\hline & Farm & Beyond the farm & & & \\
\hline Horticulture & 36.2 & 54.6 & 5.3 & 2.6 & 1.3 \\
\hline Special crop & 25.4 & 69.3 & 2.9 & 0.5 & 1.9 \\
\hline Other & 27.9 & 63.3 & 5.4 & 2.0 & 1.4 \\
\hline Total & 29.9 & 61.9 & 4.8 & 1.9 & 1.5 \\
\hline \multicolumn{6}{|l|}{ Region } \\
\hline UUSI & 25.7 & 66.7 & 7.2 & 0.4 & 0.0 \\
\hline VARS & 37.9 & 51.1 & 7.5 & 1.1 & 2.4 \\
\hline SATA & 21.2 & 74.7 & 0.9 & 2.6 & 0.7 \\
\hline HÄME & 31.7 & 63.6 & 1.6 & 0.7 & 2.4 \\
\hline PIRKA & 26.5 & 61.4 & 8.7 & 3.5 & 0.0 \\
\hline KAAK & 23.0 & 70.2 & 3.9 & 2.9 & 0.0 \\
\hline ESAVO & 39.2 & 51.9 & 7.7 & 1.2 & 0.0 \\
\hline PSAVO & 34.7 & 62.7 & 0.6 & 0.4 & 1.6 \\
\hline PKARJ & 30.2 & 62.3 & 5.1 & 2.4 & 0.0 \\
\hline KESKI & 49.4 & 50.6 & 0.0 & 0.0 & 0.0 \\
\hline EPO & 18.9 & 64.6 & 5.2 & 7.2 & 4.1 \\
\hline $\mathrm{POHJ}$ & 10.3 & 73.9 & 5.5 & 4.3 & 6.0 \\
\hline PPO & 12.4 & 83.8 & 0.9 & 0.9 & 2.0 \\
\hline KAIN & 43.1 & 38.6 & 10.3 & 8.1 & 0.0 \\
\hline LAPP & 24.7 & 75.3 & 0.0 & 0.0 & 0.0 \\
\hline ARCH & 35.0 & 54.1 & 8.4 & 2.5 & 0.0 \\
\hline
\end{tabular}

\section{Discussion}

\section{National heritage for future adaptation?}

The ancestors that gradually settled Finland and formed agrarian societies next to shorelines exploited ecosystem services that water resources represented (Jussila et al. 2007). However, having additional supply of water for irrigation of crop stands was evidently not important in a humid climate where the annual precipitation exceeded annual evapotranspiration and fields needed drainage to exploit the short growing season. Currently an average of $58 \%$ of fields has subsurface drainage systems and $27 \%$ ditches. One can consider that clearing land and establishing farms next to waterways has provided a national-cultural heritage that may enable improved adaptive capacity to cope with the forecasted, potentially harmful impacts of climate change (Rötter et al. 2011). The boreal regions of Europe thus seem to have unique opportunities to cope with potential future constraints like drought and heatwaves. When considering abundant water reserves and their availability for irrigation, there are marked differences among regions in access to water resources, as shown in Figure 1 and Figure 9.

That fields are located next to or close to the shorelines of inland waterways, poses disadvantages with associated environmental problems like eutrophication that increases as cultivation increases. Excess use of fertilizers was reported for the late 1960s to 1990s in Finland (Antikainen et al. 2008), increasing the soil phosphorus levels (acid ammonium acetate, pH 4.65, soil test phosphorus) and risk of soluble P leaching (Uusitalo and Jansson 2002). 

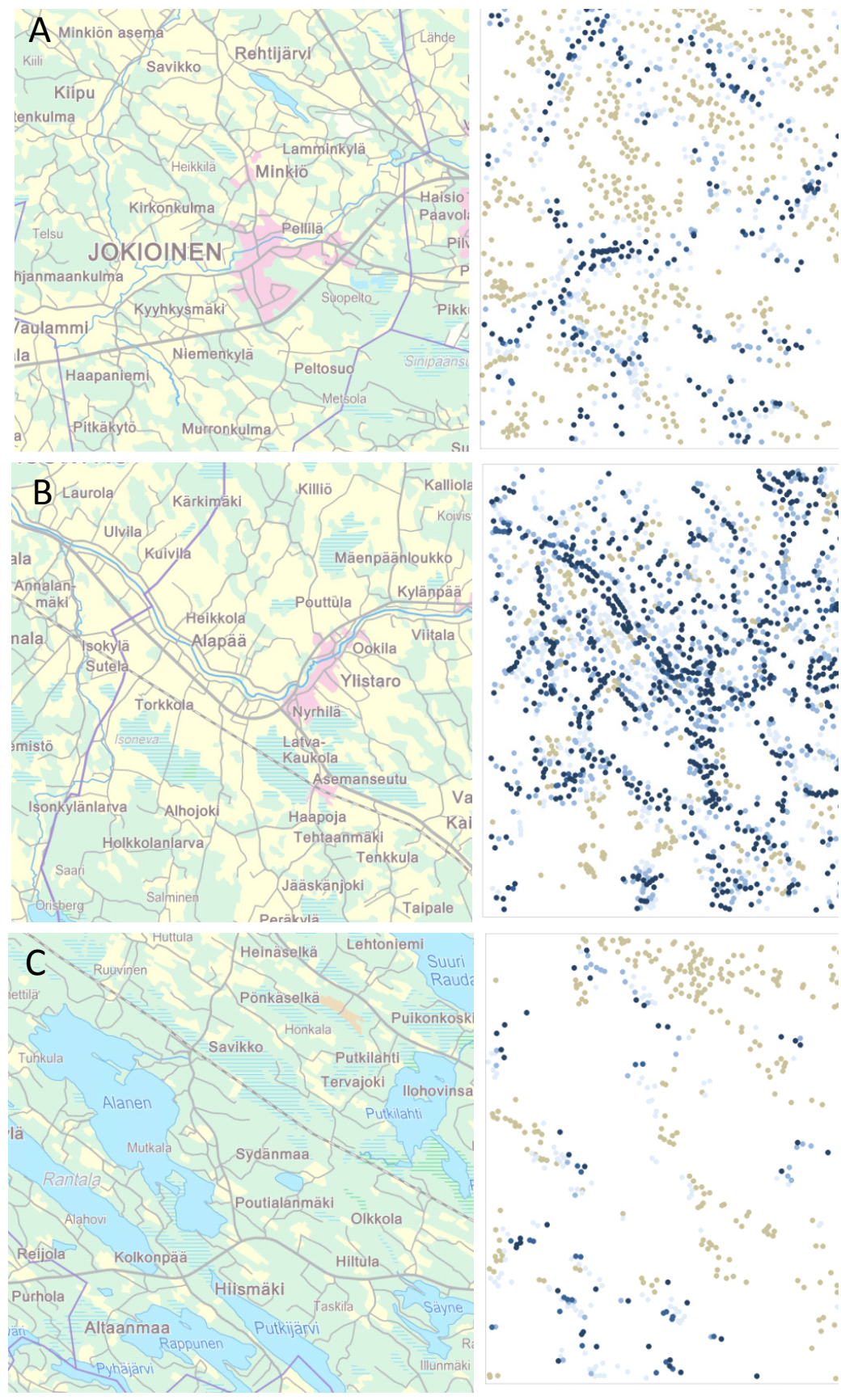

Fig. 9. Differences in frequency of fields and access to water resources depending on distance to closest waterway. On the right hand side figures, one dot indicates one field in a $10 \times 10 \mathrm{~km}$ grid. The darkest blue indicates that the field has direct contact with a shoreline of a waterway, dark blue that it is at $\leq 50$ $\mathrm{m}$ from shoreline, blue $\leq 100 \mathrm{~m}$, light blue $\leq 300 \mathrm{~m}$ apart and beige $>300 \mathrm{~m}$ apart. There are three example sites: Jokioinen (A) in Häme, Ylistaro (B) in Etelä-Pohjanmaa and Rantasalmi (C) in Etelä-Savo.

On the other hand, drought is a frequent constraint interfering with nutrient uptake and crop growth, especially in the western coastal regions (Peltonen-Sainio et al. 2011). This again emphasizes the need to consider irrigation as a means to not only close yield gaps, but also to ensure efficient nutrient uptake and thereby sustainably intensify boreal cropping systems.

Since 1995 policy incentives have been directed at reducing fertilizer use rates (Salo et al. 2007), with successful effects on reducing nutrient loads but negative impacts on yields and quality (Peltonen-Sainio et al. 2015b). However, in addition to reducing nitrogen and phosphorus use, establishing buffer zones has been incentivized, especially on sloping fields next to waterways. This targeted measure has been successful when gauged as frequency of buffer zones in fields located next to the shorelines of lakes and rivers, and allocation according to vulnerability of a region (Table 1). 
Currently irrigation is practised in Finnish horticulture (Table 5). Potato is virtually the only field crop irrigated currently and also predominantly located close to waterways in some regions (Table 1). Regarding crops other than potato, factors additional to water availability, i.e. climatic and edaphic conditions (Fig. 6), as well as other field characteristics (especially larger fields next to waterways; Fig. 3), are the predominant drivers for future land use planning. Consequently, current land use in shoreline fields does not indicate future land use, especially in the case that irrigation is introduced. Therefore, in the forthcoming assessments, one needs to also consider the potential changes in land use and shifts between crop species grown in different fields and regions depending on crops biological and economic responsiveness to irrigation. Thereby, one can more thoroughly envisage the future potential for yield elevations in a region through crop choices, associating changes in nutrient load risks and their interplay with socio-economics at the farm and regional scale. An example of recent demarcation between economics contra climatic limitations is that despite temperature conditions and adequate length of the growing season, as well as risk of night frosts (Fig. 5), spring wheat (Triticum aestivum L.) and rapeseed (Brassica rapa L.) have been cultivated more and more outside their original zones (see their share of field use e.g. in Pohjanmaa region) (Peltonen-Sainio et al. 2009, Peltonen-Sainio and Jauhiainen 2014).

\section{0 as a case of severe drought}

Drought and elevated temperatures coincided in Finland since mid-summer 2010 (Table 3) and the records were broken for the highest temperatures ever measured in July $\left(37.2^{\circ} \mathrm{C}\right)$ and August $\left(33.8^{\circ} \mathrm{C}\right)$ according to the Finnish Meteorological Institute. Simultaneously, in Russia extreme drought and the highest heat wave measured over 130 years, causing e.g. more than 550 wildfires, resulted in a food crisis (Wegren 2011). About 5.4 million hectares of crop stands shrivelled - averaging $17 \%$ of the total cropped land and impacting directly ca. 25.000 farms (Welton 2011). This caused price volatility in global food markets, and especially so in the countries that imported Russian grain. As often in a crisis, it hit the poorest (Welton 2011). Although this was a single event, and not necessarily linked with climate change, it mirrored events that are projected to become more frequent in the future (IPCC 2012) and which have been faced repeatedly in Europe during the 2000s, e.g. in 2003 and 2011 (Soussana et al. 2012). According to IPCC (2013) each of the last decades has become progressively warmer.

Finland also experienced drought and heat in 2010 and there was concern about water sufficiency for agriculture. Accumulated precipitation was less than the long-term mean for June and July across the prime agricultural regions of Finland (Table 3) and 2010 was among the years in the 2000s with the lowest spring cereal grain yields (data not shown). In addition to 2010, exceptional drought was experienced also in 2002, interfering with crop production and animal welfare and production (Silander and Järvinen 2004). Regarding the drought of summer 2010, statistics (Tike 2012) indicate than only $3 \%$ of arable land had access to irrigation, mainly because of lack of technologies, yet at the national scale $23 \%$ of fields are located next to the shoreline of a waterway and even $72 \%$ are $\leq 300 \mathrm{~m}$ from water (Fig. 1). In general, fields in the most drought prone coastal regions have often an advantage of access to irrigation machinery and water over the inland regions. As the fields next to shorelines are typically larger than those elsewhere, access of the whole field to water could be limited. Irrigation again is practised almost solely for horticulture and potato production (Table 3). Even in the case of severe drought and elevated temperatures that occurred in 2010 , only part of the irrigation potential (corresponding $<20 \%$ of area accessible for irrigation) was harnessed, mainly by exploiting surface water resources (Tables 4 and 5 ). Also the historical reallocation of parcels of land may have resulted in farm structures unsuited to irrigation (Hiironen and Ettanen 2012).

It is likely that the major limiting factor for exploiting even the currently existing irrigation potential in today's socio-economic framework is insufficient in economic incentives to invest in irrigation equipment and/or to expand the current technology to watering crops other than horticultural cash crops (Peltonen-Sainio et al. 2015a). However, the current incentives for irrigation may differ markedly from those envisaged for the future in a changing climate. The projected increasing challenges regarding water sufficiency (Peltonen-Sainio et al. 2011) and elevated temperatures (Rötter et al. 2011), as well as the anticipated increases in weather variability and frequency of extreme events (IPCC 2012), in addition to a projected longer growing season and higher yield potentials (PeltonenSainio et al. 2009), call for including irrigation as an element in adaptation strategies and implementation plans.

This survey highlighted the reasonably high irrigation potential resulting from one third of Finnish fields being in direct contact with a shoreline of an inland waterway, especially in western coastal regions with the lowest early season precipitation and highest pressure evapo-transpiration (Pajula and Triipponen 2003; Peltonen-Sainio etal. 2011). However, under high latitude long-day conditions the period for the most acute need for additional water to sustain crop stands is short. 
Hence, when targeting irrigation technologies to supply additional water to crop stands during their most vulnerable, drought prone phase, sufficiency of water for contemporary, potentially even large-scale irrigation, is uncertain (Peltonen-Sainio et al. 2015a). This again calls for comprehensive assessments of water sufficiency for future irrigation schemes. Besides the sufficiency of water for irrigation, possible limitations to using water resources for irrigation must be taken into account. In the future studies on field water management, irrigation systems should be considered together with drainage systems to assess the opportunities to gain from water collection systems and/or temporary storage (e.g. constructed wetlands).

\section{Conclusions}

Monitoring access to abundant water reserves in Finland emphasized the general potential to expand irrigated areas in the future in the case that drought episodes and elevated temperatures will be experienced more frequently due to climate change. However, the development of water management systems will differ depending on region and further steps to be taken along with technological developments call for thorough considerations of water sufficiency and availability for large-scale irrigation needed for a relatively short time period. Also socioeconomic obstacles, like farmers' inexperience in irrigation in field crop production and the diffuse farm structure, and thereby the potential reluctance to invest, needs to be taken into consideration. To support long-term decision-making processes at the national scale and to better envisage the future gains potentially achievable by irrigation, calls for comprehensive evaluation of differences in yield potentials, attainable yields and yield losses caused by drought under future climatic conditions for different regions. Factors other than water availability (field characteristics, environmental concern etc.) are current drivers for land use planning in the shoreline fields and consideration has therefore to be given to the land use changes in shoreline and distant fields. Depending on yield gaps and responsiveness of crops to irrigation, greater understanding is needed on the future potential of irrigating Finnish fields.

\section{Acknowledgements}

The work was financed by the Finnish Ministry of Agriculture and Forestry as a part of a consortium project titled Water Management Systems to Improve Energy and Nutrient Use Efficiency of Field Crop Production in Changing Climate (VEHMAS) and by MTT Agrifood Research Finland as a part of a project Sustainable Intensification of Cropping Systems (SusIntens).

\section{References}

Antikainen, R., Haapanen, R., Lemola, R., Nousiainen, J.I. \& Rekolainen, S. 2008. Nitrogen and phosphorus flows in the Finnish agricultural and forest sectors, 1910-2000. Water, Air \& Soil Pollution 194: 163-177.

Baker, J.M., Everett, Y., Liegel, L. \& van Kirk, R. 2014. Patterns of irrigated agricultural land conversion in a Western U.S. watershed: Implication for landscape-level water management and land-use planning. Society and Natural Resources 27: 1145-1160.

FLPIS 2014. Finnish Land Parcel Identification System register web site administered by MAVI and NLS. Cited 28 July 2014 . http:// www.mavi.fi/en/support-and-services/Pages/default.aspx and http://www.paikkatietoikkuna.fi/web/en/map-window.

Hansen, B.R. 1998. Early agrarian landscapes in Finland. Geografiska Annaler 80: 187-201.

Hiironen, J. \& Ettanen, S. 2012. Peltoalueiden tilusrakenne ja sen parantamismahdollisuudet. Maanmittauslaitoksen julkaisuja nro 113. 82 p. (In Finnish).

IPCC 2012. Summary for Policymakers. In: Field, C.B., Barros, W., Stocker, T.F., Qin, D., Dokken, D.J., Ebi, K.L., Mastrandrea, M.D., Mach, K.J., Plattner, G.-K., Allen, S.K., Tignor, M. \& Midgley, P.M., (eds). Managing the Risks of Extreme Events and Disasters to Advance Climate Change Adaptation. A Special Report of Working Groups I and II of the Intergovernmental Panel on Climate Change, Cambridge, Cambridge University Press. 19 p.

IPCC 2013. Summary for Policymakers. In: Stocker T.F., Qin D., Plattner G.-K., Tignor M., Allen S.K., Boschung J., Nauels A., Xia Y., Bex V. \& Midgley P.M. (eds). Climate Change 2013: The Physical Science Basis. Contribution of Working Group I to the Fifth Assessment Report of the Intergovernmental Panel on Climate Change, Cambridge, Cambridge University Press. 28 p.

Jury, W.A. \& Vaux, H.J. Jr. 2007. The emerging global water crisis: Managing scarcity and conflict between water users. Advances in Agronomy 95: 1-76.

Jussila, T., Kriiska, A. \& Rostedt, T. 2007. The Mesolithic settlement in NE Savo, Finland and the earliest settlement in the eastern Baltic Sea. Acta Archaeologica 78: 143-162.

Lilja, H., Uusitalo, R., Yli-Halla, M., Nevalainen, R., Väänänen, T. \& Tamminen, P. 2009. Suomen Maannostietokanta. MTT TIEDE 6. 69 p. Helsinki, Finland. (In Finnish with English abstract)

NLS 2014. National Land Survey of Finland (NLS) topographic dataset. Cited 28 July 2014. http://www.paikkatietoikkuna.fi/web/ $\mathrm{fi} /$ maastotietokanta. 
Pajula, H. \& Triipponen, J-P. 2003. Selvitys Suomen kastelutilanteesta, esimerkkialueena Varsinais-Suomi. (A survey of the irrigation in Finland - case study Southwestern Finland). Suomen ympäristö, No. 629. 86 p. ISBN 952-11-1416-9 (In Finnish)

Peltonen-Sainio, P. 2012. Crop production in a northern climate. In: Meybeck, A., Lankoski, J., Redfern, S., Azzu, N. \& Getz, V. Proceedings of a Joint FAO/OECD Workshop, Building Resilience to Climate Change in the Agriculture Sector. p. 183-216. Cited 2 July 2014. http://www.fao.org/agriculture/crops/news-events-bulletins/detail/en/item/134976/

Peltonen-Sainio, P., Jauhiainen, L. \& Venäläinen, A. 2009. Comparing regional risks in producing turnip rape and oilseed rape - Today in light of long-term datasets. Acta Agriculturae Scandinavica, B Soil and Plant Science 59: 118-128.

Peltonen-Sainio, P., Jauhiainen, L. \& Hakala, K. 2011. Crop responses to temperature and precipitation according to long-term multi-location trials at high-latitude conditions. Journal of Agricultural Science 149: 49-62.

Peltonen-Sainio, P. \& Jauhiainen, L. 2014. Lessons from the past in weather variability: sowing to ripening dynamics and yield penalties for northern agriculture in 1970-2012. Regional Environmental Change 14: 1505-1516.

Peltonen-Sainio, P., Jauhiainen, L. \& Alakukku, L. 2015a. Stakeholder perspectives for switching from rainfed to irrigated cropping systems at high latitudes. Land Use Policy 42: 585-593.

Peltonen-Sainio, P., Salo, T., Jauhiainen, L., Lehtonen, H. \& Sieviläinen, E. 2015b. Static yields and quality issues: Is the Agri-Environment Program with reduced fertilizer use rates the primary driver? AMBIO, DOI: 10.1007/s13280-015-0637-9

Pollmann, B. 2014. Environment and agriculture of the transitional period from the Late Bronze to early Iron Age in the eastern Baltic: an archaeobotanical case study of the lakeshore settlement Luokesa 1, Lithuania. Vegetation History \& Archaeobotany 23: 403-418.

Rötter, R.P., Palosuo, T., Pirttioja, N.K., Dubrovsky, M., Salo, T., Ristolainen, A., Fronzek, S., Aikasalo, R., Trnka, M., Carter, T.R., 2011. What would happen to barley production in Finland if global warming exceeded $4{ }^{\circ} \mathrm{C}$ ? A model-based assessment. European Journal of Agronomy 35: 205-214.

Salo, T., Lemola, R. \& Esala, M. 2007. National and regional net nitrogen balances in Finland in 1990-2005. Agricultural and Food Science 16: 366-375.

Silander, J. \& Järvinen, E.A. 2004, Vuosien 2002-2003 poikkeuksellisen kuivuuden vaikutukset (Effects of Severe Drought of 2002/2003). Suomen ympäristö 731.79 p. (In Finnish).

Soussana, J.F., Fereres, E., Long, S., Mohren, F.M.J., Panday-Lorch, R., Peltonen-Sainio, P., Porter, J.R., Rosswall, T. \& von Braun, J. 2012. A European science plan to sustainably increase food security under climate change. Global Change Biology, Letter 18: 3269-3271.

Taavitsainen, J.-P., Simola, H. \& Grönlund, E. 1998. Cultivation history beyond the prephery: early agriculture in the North European Boreal forest. Journal of World Prehistory 12: 199-253.

Tike 2012. Maatalouslaskenta 2010. Kastelu avomaalla ja energia. 16 p. Cited 30 June 2014. http://www.maataloustilastot.fi/e-lehti-kastelu-energia/

Uusitalo, R. \& Jansson, H. 2002. Dissolved reactive phosphorus in runoff assessed by soil extraction with an acetate buffer. Agricultural and Food Science in Finland 11: 343-353.

Wallin, J.-E. \& Segerström, U. 1994. Natural resources and agriculture during the Iron Age in Ostrobothnia, western Finland, investigated by pollen analysis. Vegetation History \& Archaeobotany 3: 89-105.

Wegren, S.K. 2011. Food security and Russia's 2010 drought. Eurasian Geography and Economics 52: 140-156.

Welton, G. 2011. The impact of Russia's 2010 grain export ban. Oxfam Research Reports, June 2011: 32 p. http://www.oxfam. org/en/grow. Accessed 1 July 2014.

Zvelebil, M. \& Rowley-Conwy, P. 1984. Transition to farming in northern Europe: A hunter-gatherer perspective. Norwegian Archaeological Review 17: 104-128. 